\title{
Market and Banking Competition in the Frame of the Financial Crisis: Albanian Case
}

\author{
Phd. Can. Ardian Muçi \\ PhD candidate at the Faculty of Economy and Agribusiness; Agricultural University of Tirana \\ Prof. Drini Salko \\ Lector on "Finance at the Faculty of Economy and Agribusiness; Agricultural University of Tirana \\ Phd. Fehmi Azemi \\ Manager of RIMA Company, Pristina Kosovo
}

\section{Doi:10.5901/ajis.2016.v5n3s1p100}

\begin{abstract}
Albanian banking system is the most developed component of the financial system. Since the creation of the Albanian banking system with two levels in 1992, and its subsequent liberalization, the Albanian banking market has undergone substantial changes. Albanian banking system consists of 16 wholly owned private banks of which the majority are foreign-owned and only 3 are domestically owned banks. The main purpose of this paper is to study the Albanian banking market over the last decade through indicators that express market competition as one of the main directions of its development. The article refers to the beginning period of the global financial crisis which had an impact in the Albanian banking market. To achieve this goal are used theoretical knowledge and indexes that are used to calculate the level of competition in the banking market. Working methodology is based on statistical analysis of secondary data obtained from the Bank of Albania, commercial banks operating in Albania, the Albanian Ministry of Finance etc. Through the analysis of market indexes will try to give an overview on the current situation of the Albanian banking market. The end will conclude in several features highlighting banking markets in Albania and provide some recommendations based on the experience of other countries and the opportunities for such development in the Albanian banking market.
\end{abstract}

Keywords: banking market, loans, deposits, index

\section{Introduction}

Since the creation of two-tier banking system in 1992, and its subsequent liberalization, the Albanian banking market has undergone substantial changes. Albanian banking system consists of 16 private wholly owned bank extended to over 499 branches, of which the majority are foreign-owned and only 3 are domestically owned banks. However, although the ownership of the banking system is no longer in the hands of the state, it has increased public confidence in banks, significantly affected by the 1997 crisis and the banking panic of 2002. New banking products are born and developed. Services such as payment cards or online payments are functional in some banks of the Albanian banking system. There is a market added to credit risk with an unrivaled level to the first years of transition. Along with the increase of the number of banks is also increased the number of bank branches and agencies.

However, although so far are positive developments still we can not say that we have a properly developed banking system. There are still problems and dysfunction of the system in several ways. Although the level of debt in recent years has been increasing again intermediation remains low. Many individuals or commercial companies are not able to be financed by banks. The loan / deposit ratio presented in December 2015 level and $56.5 \%$ reflects a balanced structure of asset-liabilities at the system level. On the other hand interest rates on loans, even though they tended to decrease levels are still high and still deposit interest margin is also higher. Despite the first signs of competition the market continues to remain concentrated in a few banks. These and other developments come not only of being a banking system with a relatively young population but also by the level of competition in this sector. 


\section{Analysis of the Albanian Banking System Development and Competitiveness in the Market}

The banking sector remains the main segment of financial intermediation in Albania. In late 2015, his assets to GDP recorded a $87 \%$ level. The banking sector is dominated by five large banks, which together constitute $67 \%$ of the loan portfolio and $73 \%$ of system deposits. Most of the banking sector is controlled by subsidiaries of foreign banking groups with capital originating from the European Union and to exercise their activities based on the Albanian legislation and all applicable regulatory framework of the Bank of Albania.

At the end of 2015, banking sector assets grew to 1,234 billion level, marking an annual growth of $3.9 \%$, from $6.1 \%$ registered a year ago. This slowdown was due to lower growth in deposits and decrease the commitment of banks in the lending process. Expansion of assets is realized through operations in the interbank market and the securities, mainly reflecting growth sector participation in auctions of government debt securities. Financing activity is provided by the growth of deposits from the public, which occupied $82.1 \%$ of total liabilities of the banking sector. Despite moderate economic activity, bank deposits grew by $3.6 \%$ in 2015 . This increase was lower, compared with the previous year of $7.3 \%$.

During the second half of 2014, lending activity of the banking sector shrank by $1.8 \%$. At the end of 2014 , lending activity is estimated at about $41.3 \%$ of GDP. The net financial result of the banking sector at the end of the year was positive, with a value of around 6.6 billion

Approvals for conducting additional bank licenses annexes, in 2014, consisted in the evaluation of the requirements of the two banks to increase the activity of insurance and reinsurance mediation (for Raiffeisen Bank). As well as the approval for conducting additional activity of providing guarantees and commitments, and trading on behalf of clients even in a foreign exchange, in a self-organized market of transferable securities (for Intesa Sanpaolo Bank Albania). It is worth mentioning that the performance of the intermediary activity in insurance and reinsurance is an innovation in the activity of banks and finalization of changes made to the regulation of licensing banks a year ago, which expanded the spectrum of banking and financial activities carried out by banks, including those activities. Also, attractive appears this activity for other banks in the system, which are in the application process or interest, in terms of meeting the conditions for its performance. During this year, banks submitted requests to change their network, both in terms of expansion as well as the reduction of branches and agencies within the country.

In 2015 there were no changes in the number of entities operating in the non-banking financial market, after being awarded three new licenses for the operation of financial leasing and factoring, and was also 3 other licenses revoked. 3 Revocation of licenses to non-bank financial entities is a result of: initiating a financial activity as a result of the merger by absorption with a commercial bank and at the request of the subject. In keeping with the Principle of restraining competition, regulators support a market with a moderate level of competition. There are many ways to draw a bank structure in an economy depending on the weight that different banks keep banking market

At the end of December 2015, the Albanian banks of the banking sector are divided by size of activity:

- Banks of Group 1 (each holds 0-2\% of total banking sector assets): United Bank of Albania (UBA), Veneto Bank (VB), International Commercial Bank (ICB), First Investment Bank (FIB) Bank, credit Bank of Albania (NBA); American Investment Bank (BAl). These banks account for about $6.5 \%$ of total banking sector assets.

- Banks of Group 2 (each holds 2-7\% of total banking sector assets), ProCredit Bank (BPC), the National Bank of Greece (NBG), Societe Generale Bank - Albania (BSG), Alpha Bank - Albania (BA) Bank Union (BU), Tirana Bank (BT). These banks account for about $24.1 \%$ of total banking sector assets.

- Banks of Group 3 (each owns about 7\% of total banking sector assets), National Commercial Bank (NCB), Raiffeisen Bank (BR), Credins Bank (BC), Intesa Sanpaolo Bank-Albania (ISBA). These banks account for about $69.3 \%$ of total banking sector assets.

\section{Albanian Banking Market and Competition in it}

In a market economy, the regulatory and supervisory framework of the banking market tends to restrict competition in the market. Because of this influence, the practice may encounter two forms of the market:

- banking markets dominated by a single bank

- banking markets concentrated in a small number of banks.

A banking market is said to be dominated by one single bank when the bank owns over $50 \%$ of deposits and loans in the market. In such a situation this bank is price decisive and the market price takes the form of a monopolistic competition. The dominant bank sets interest rates and are a large number of small banks in the market which compete 
among themselves with the interest rate that has defined the dominant bank.

A concentrated banking market is called when a small number of banks own the majority of the market (more than $70 \%$ of it). In such a market, major banks compete moderately to one another not showing signs of aggressiveness in the market.

It is often acknowledged that a part of a market failure is resolved through increased competition. It is precisely the lack of it which leads to part of the problems of the market. Prevalence and concentration are two indicators that show the level of competitiveness of the banking market. A banking system, whose activities are dominated by a bank or are concentrated in a few banks, has a low level of competition.

In particular, the dominance of the banking system occurs when a single bank controls a large part of the market. Naturally different countries have set different quotas on which a bank is defined as the dominant banking system. In Albania's case a bank is defined as dominant in the banking market if it owns over $40 \%$ of the market. While the prevalence of the system from a single bank is rare, banking systems concentrated on a small group of banks is a phenomenon that occurs most often. But, just like the banking market dominated by a single bank, also the banking market whose activities are concentrated on a small number of banks, have a low level of competition and a high level of $\mathrm{H}$ index that measures precisely the concentration of a banking system.

Competition in banking markets is estimated by a number of indicators. An important indicator which shows competitiveness is $\mathrm{H}$ index (Herfindaflit) which is a measure of the concentration level of the banking system of the country. A high index indicates a high level of concentration and consequently a low level of competition. A lower index indicates a low level of concentration which is a sign of a banking market with high competition. Calculations of this index are particularly important for assets, deposits and loans of the banking system.

$\mathrm{H}$ index values are smaller than 1 and greater than the average share of the banking system. Thus, a banking system like ours of 16 banks, the average share for each bank is considered $1 / 16=0.0625$ or $6.25 \%$. The meaning of this report is this: if each bank would have $6.25 \%$ of the market share then the market would be distributed equally to all banks so the competition would be high and there would be no concentration. In contrast, in conditions when one or several banks own most of the market then we say that the competition is low and the concentration is high. In such a situation, the index value is close to the number 1 . Since 1994, after the liberalization of the banking system and the entry of several foreign banks, there were two periods of change scale prevalence of the banking system.

The first period, which starts in 1994 until 2000 is characterized by a significant increase of the level of prevalence of the banking system by the Savings Bank. In 1994, the Savings Bank's assets accounted for only 18\% of the market whereas in 2000 this bank's assets accounted for $63.3 \%$ of the market. The same has happened in the deposit's market. From $47.6 \%$ of the deposits collected by Savings Bank in 1994 its share in the deposit market went to $71.3 \%$ in year 2000.

The banking system underwent a significant change after year 1997. After this year, the Savings Bank significantly increased its market share. So this bank's assets increased from 29\% market share in 1996 to $62.7 \%$ in 1997. This marked the beginning of significant market dominance by the Savings Bank.

After year 2000, with an increase in the number of banks and their market share, the market share of the Savings Bank began to fall, which continued falling even after its privatization. Currently we can say that the prevalence of Raiffeisen Bank has fallen significantly and the the competitiveness of the banking system has began to be felt. By the owning of $63.3 \%$ of the banking system assets in 2000 by the Savings Bank, now it owns approximately $22.7 \%$ of assets. The market share of other banks has increased. A growing weight is being taken by several other banks like National Commercial Bank (BKT), Intesa San Paolo Bank, Tirana Bank, etc. Thus Intesa San Paolo, in late 2000, owned 4.37\% of the assets of the Albanian banking system. During the 14 years this bank's assets have multiplied, increasing its market share to $11.7 \%$ at the end of 2014. Meanwhile, for the same period, the share of Raiffeisen bank has marked a decrease in its share from $63.29 \%$ at the end of 2000 , to $22.7 \%$ of banking system assets at the end of year 2014 .

This situation is also demonstrated by the $\mathrm{H}$ index values. Based on the data of the past 11 years we note a decrease in the $\mathrm{H}$ index due to a lower dominance of Raiffeisen Bank in the market.

\begin{tabular}{|l|c|c|c|c|c|c|c|c|c|c|}
\hline Year & $\mathbf{2 0 0 6}$ & $\mathbf{2 0 0 7}$ & $\mathbf{2 0 0 8}$ & $\mathbf{2 0 0 9}$ & $\mathbf{2 0 1 0}$ & $\mathbf{2 0 1 1}$ & $\mathbf{2 0 1 2}$ & $\mathbf{2 0 1 3}$ & $\mathbf{2 0 1 4}$ & $\mathbf{2 0 1 5}$ \\
\hline Index H for Assets & 0.21 & 0.18 & 0.15 & 0.15 & 0.14 & 0.15 & 0.15 & 0.14 & 0.14 & 0.15 \\
\hline Index H for Deposits & 0.24 & 0.2 & 0.17 & 0.17 & 0.15 & 0.16 & 0.15 & 0.14 & 0.14 & 0.15 \\
\hline Index H for Loans & 0.1 & 0.11 & 0.12 & 0.11 & 0.11 & 0.11 & 0.12 & 0.12 & 0.12 & 0.12 \\
\hline
\end{tabular}

Source: Bank of Albania; Statistics Report .2015 
As shown in the table above, from 2006 to 2015 Index $\mathrm{H}$ has decreased from 0.21 to 0.14 mainly in assets and from 0.24 to 0.14 in deposits and only in 2015 this indicator shows a slight improvement. The loan market also has a drop of index $\mathrm{H}$ from 0.1 in year 2006 to 0.12 in year 2015. The loan market is to be seen separately because this market has had lower levels of $\mathrm{H}$ index during the entire review period. This indicates a higher level of competition in this market.

After 2006 a decline in the prevalence rate in the market and an increased competition are apparent. The prevalence of Raiffeisen bank is below the level set by law. Currently the bank owns less than $25 \%$ of the banking system assets. Market developments have made it so that the market share previously owned by the Savings Bank now its owned by three banks. While other small banks occupy each a symbolic market share which is an evidence that the concentration of the market now is no longer on a single bank but on a small number of banks.

So, despite the decreased prevalence we can say that the new trend is towards the concentration of the banking system in a small number of banks that make up the majority of the Albanian banking market.

Therefore if in year 2000 the Savings Bank owned $63.29 \%$ of the market, at the end of 2014 roughly the same market share is owned by three banks, RZB, BKT and BASH which together have $61.3 \%$ of the total assets of the Albanian banking system.

A similar situation occurs in the deposit market. Market dominance by Raiffeisen Bank is softened. From $71.4 \%$ of the deposits market occupied by the Savings Bank in 2000, Raiffeisen Bank collected 23.9\% of deposits in 2015 .. Similarly as in the asset market, in the market of deposits the three largest banks account for roughly $60 \%$ of the market in 2015. The following table shows data for the Albanian banking market sharing.

Table 2: Distribution of assets, deposits and loans for year 2015

\begin{tabular}{|c|c|c|c|c|c|c|}
\hline Nr Bankat & Vlera & $\begin{array}{l}\text { Aktivet } \\
\text { Pesha }\end{array}$ & Vlera & $\begin{array}{l}\text { Loans } \\
\text { Pesha }\end{array}$ & Vlera & $\begin{array}{c}\text { Deposits } \\
\text { Pesha }\end{array}$ \\
\hline 1 Alpha Bank Albania & 81,815 & $6.4 \%$ & 34,709 & $6.2 \%$ & 67,500 & $6.5 \%$ \\
\hline \begin{tabular}{|l|l|}
2 & National Commercial Bank \\
\end{tabular} & 272,543 & $21.3 \%$ & 90,268 & $16.1 \%$ & 219,433 & $21.3 \%$ \\
\hline \begin{tabular}{|l|l|}
3 & Credins Bank \\
\end{tabular} & 107,965 & $8.4 \%$ & 67,469 & $12.0 \%$ & 91,965 & $8.9 \%$ \\
\hline \begin{tabular}{|l|l|}
4 & Credit Bank of Albania \\
\end{tabular} & 1,762 & $0.1 \%$ & 249 & $0.0 \%$ & $\overline{513}$ & $0.0 \%$ \\
\hline \begin{tabular}{|l|l|}
5 & Credit Agricole \\
\end{tabular} & 30,510 & $2.4 \%$ & 21,269 & $3.8 \%$ & 19,025 & $1.8 \%$ \\
\hline \begin{tabular}{|l|l|}
6 & Fibank Albania \\
\end{tabular} & 17,063 & $1.3 \%$ & 6,508 & $1.2 \%$ & 15,406 & $1.5 \%$ \\
\hline \begin{tabular}{|l|l|}
7 & International Commercial Bank \\
\end{tabular} & 9,189 & $0.7 \%$ & 2,842 & $0.5 \%$ & 6,820 & $0.7 \%$ \\
\hline \begin{tabular}{|l|l|}
8 & Intesa Sanpaolo Bank Albania \\
\end{tabular} & 149,399 & $11.7 \%$ & 50,912 & $9.1 \%$ & 114,700 & $11.1 \%$ \\
\hline \begin{tabular}{l|l}
9 & NBG Bank Albania \\
\end{tabular} & 44,352 & $3.5 \%$ & 24,369 & $4.3 \%$ & 33,625 & $3.3 \%$ \\
\hline 10 ProCredit Bank & 40,711 & $3.2 \%$ & 23,006 & $4.1 \%$ & 32,442 & $3.1 \%$ \\
\hline \begin{tabular}{|l|l|}
11 & Raiffeisen Bank Albania \\
\end{tabular} & 290,561 & $22.7 \%$ & 127,997 & $22.8 \%$ & 246,385 & $23.9 \%$ \\
\hline 12 Societe Generale Albania & 69,994 & $5.5 \%$ & 37,620 & $6.7 \%$ & 56,688 & $5.5 \%$ \\
\hline \begin{tabular}{|l|l|}
13 & Tirana Bank \\
\end{tabular} & 101,580 & $7.9 \%$ & 43,995 & $7.8 \%$ & 78,630 & $7.6 \%$ \\
\hline 14 Union Bank & 32,675 & $2.6 \%$ & 14,246 & $2.5 \%$ & 27,235 & $2.6 \%$ \\
\hline
\end{tabular}

Source: Annual Report: Bank of Albania, 2015

The data for assets, deposits and loans demonstrate the concentration of most of the market share in 3 main banks, RZB, BKT and ISP, which own $55.7 \%$ of the banking system assets; $58.2 \%$ of deposits collected and $48 \%$ of the market of distributed loans, showing the concentration of the market, especially that of assets and deposits, in these three banks.

These data reveal once again the low level of concentration in the loan market, an indicator of high competition in this market. There are 11 banks that occupy a significant part in the loan market, starting from the Commercial Bank of Greece which occupies $4.96 \%$ of the market and continuing with other banks which occupy greater share of the market to the main lead, Tirana Bank, which occupies $13.36 \%$ of the loan market.

The current level of concentration of the Albanian banking system is influenced by the presence of several banks with a very low level of activity. Hence, 6 banks together account for less than 3\% of the market share. Specifically these banks own $2.81 \%$ of the assets of the banking system and have been able to accumulate only $1.95 \%$ of the deposit. A loan volume of 5.1 billion ALL, accounts for only $2.59 \%$ of the loan market. Most part of these banks have been licensed for years but still, they have not managed to occupy a significant portion of the market. Naturally, this has affected the level of concentration of the banking system, by not pressured for further increase of competition in the market. 


\section{Conclusions and Recommendations}

By analyzing the results of the index $\mathrm{H}$ market loans, deposits and assets we can say that the Albanian banking market is a market partly focused. This conclusion demonstrates the fact that three to four Albanian banking system banks own over $50 \%$ of the market.

Analyzing quantitative data related to deposits, loans and asset for the past 10 years as well as parallel index values over the last 19 years we can say that the Albanian banking system has been transformed from a market dominated by Raiffeisen Bank, in a market concentrated by three to four banks that belong to the group G3. This development has increased the range of banking services, providing them with a quality similar to banks in countries of the European Union and at an acceptable cost to consumers of banking services in Albania.

For a further increase in banking competition in Albania as promoter of this market we think:

- Albanian banking market should increase the range of banking services and their quality in order to offer products up to date with current developments and also offer competitive prices and suitable to the users of banking services.

- It is necessary to find such instruments to encourage a more lending economy by banks and to increase the competition in the credit market. Currently, interest rates on loans have declined but still remain at high levels compared to other regional countries. The downward trend of interest rates on loans is lower than the downward trend of interest rates on deposits. At the same time, the decline of the base interest rate was an incentive to decrease further the interest rate on loans. A more competitive market will provide loan interest rates that not only serve the banking productivity, reduce banking risks but also promoting the economy, especially in a crisis such as that of European countries, a crisis by which the Albanian economy is also affected.

- It is necessary licensing of local banks with limited activity only in some areas of the country. Macedonia's example is a good opportunity to see the benefits of an expansive sector to the local banks. The greatest benefits in this regard I think that will have the agricultural sector which still suffers from a lack of bank financing.

- Stimulation of credit growth by banks to agriculture and agro-processing sector through implementation of a rapid plan of the Credit Guarantee Fund, already begun to be implemented by the government would increase the competition in the banking market.

\section{References}

"The Economics of Money, Banking and Financial Markets," Frederic Mishkin, 2015

Bernanke, B. S., \& Gertler, M. (1986). Agency costs, collateral, and business fluctuations.

Bernanke, B. S., \& Gertler, M. (2001). Should central banks respond to movements in asset prices?. american economic review, 253257.

Blejer, M. I. (2007). Asset prices, globalization, and implications for monetary policy. Comparative Economic Studies, 49(3), 339-344.

Wgert, B., \& Mihaljek, D. (2007). Determinants of house prices in Central and Eastern Europe. Comparative economic studies, 49(3), 367-388.

Feldstein, M. S. (2007). Housing, credit markets and the business cycle (No. w13471). National Bureau of Economic Research.

Monitoring Report, 2015, the Bank of Albania

RZB Annual Report, 2004, 2005, 2006, 2007, 2008, 2009, 2010, 2011, 2012, 2013.2014, 2015

NCB Annual Report 2001, 2002, 2003, 2004, 2005, 2006, 2007, 2008, 2009, 2010, 2011, 2012, 2013.2014

ABA Annual Report, 2003, 2004, 2005.2006, 2007, 2008, 2009, 2010, 2011, 2012, 2013.2014

BIA Annual Report, 2002, 2003, 2004, 2005.2006, 2007, 2008, 2009, 2010, 2011, 2012, 2013.2014

Statistical Report, the fourth quarter of 2006, 2007, 2008, 2009, 2010, 2011, 2012, 2013.2014 